University of Nebraska - Lincoln

DigitalCommons@University of Nebraska - Lincoln

Publications from USDA-ARS / UNL Faculty

U.S. Department of Agriculture: Agricultural

Research Service, Lincoln, Nebraska

November 2002

\title{
Handbook of Plant and Crop Physiology, Second Edition, Revised and Expanded
}

Wally Wilhelm

University of Nebraska-Lincoln, wally.wilhelm@ars.usda.gov

Follow this and additional works at: https://digitalcommons.unl.edu/usdaarsfacpub

Part of the Agricultural Science Commons

Wilhelm, Wally, "Handbook of Plant and Crop Physiology, Second Edition, Revised and Expanded" (2002). Publications from USDA-ARS / UNL Faculty. 73.

https://digitalcommons.unl.edu/usdaarsfacpub/73

This Article is brought to you for free and open access by the U.S. Department of Agriculture: Agricultural Research Service, Lincoln, Nebraska at DigitalCommons@University of Nebraska - Lincoln. It has been accepted for inclusion in Publications from USDA-ARS / UNL Faculty by an authorized administrator of DigitalCommons@University of Nebraska - Lincoln. 
Handbook of Plant and Crop Physiology, Second Edition, Revised and Expanded. Edited by M. PESSARAKLI. Marcel Dekker, Inc., 270 Madison Avenue, New York, NY 10016. 2002. Hardcover, 973 pp., \$225.00. ISBN 0-8247-0546-7.

This book, as the title states, is an updated and expanded edition of a 1995 book with a similar title and the same editor. The first thing that may strike the reader of the Handbook is the physical size of this volume. Although the second edition is a few pages shorter than the original (973 vs. 1003 pages), the print size was reduced in this revised edition allowing the expanded text to be presented in a similar number of pages. In revising the book, the editor and authors have rearranged the sections, updated almost all chapters, and added chapters on topics not covered in the original edition. The editor states that between 65 to $80 \%$ of the material in this edition is new material. In reading the chapters and comparing selected passages between the two editions, this claim maybe a bit of an exaggeration, but rest assured that a great quantity of new material and information was added. In some cases, authors of chapters that occur in both editions have also changed.

One important assessment that must be provided by any book reviewer is the intended use and audience for the book under review. Dr. Pessarakli states in the Preface to the book, "The concepts have been presented to allow both beginning students and specialists of this discipline an opportunity to expand and refine their knowledge." My training and experience in the broad range of topics covered in this book encompasses the full range of expertise defined by the editor, from beginning students to specialist. In reading chapters dealing with areas where I have little or no knowledge, the presentation of information was too advanced to fully comprehend. Conversely, in areas where I have greater knowledge and 
practical experience, I found some of the chapters lacking detail and nuance. Stating these contrasting impressions is not meant to commend or condemn the text. This statement likely indicates that the authors have, in general, achieved their goal, challenging the novice and validating the expert.

I was impressed (in some cases astounded) by the number of references cited in many chapters of the book. Most of the chapters are between 10 and 20 pages long and have well over 100 citations. In fact several chapters are supported by over 300 citations. The abundant references should aid the novice in gathering the additional information needed to appreciate fully concepts introduced with insufficient detail for complete comprehension. Likewise, data, discussion, and alternative concepts in cited references will expand on a briefly explained topic for the expert. One point of inconsistency was observed in comparing reference sections of the various chapters. In some chapters, the complete citation (author, title, source, volume, pages, and year) was used; in others, a shorter format for listing references was used (the paper title was eliminated). In addition, in a few chapters, both methods of listing references were used. Even though I much prefer that titles of cited references be listed because of the additional information that gives the reader about the reference, the lack of consistency within and among chapters is more disconcerting than the lack of titles listed for a number of references.

A notable shortcoming of several chapters is a lack of informative figures. We are aware that students, at all levels, use different learning styles. Some are characterized as verbal learners; they are well served by the text in all chapters. Unfortunately, visual learners are not as well served. I contrast the Handbook of Plant and Crop Physiology, Second Edition (this volume) with Biochemistry and Molecular Biology of Plants by Buchanan et al. (2000). In the latter, it is difficult to find a page without a table, figure, illustration, or photograph to assist the learner in understanding concepts or processes. In addition, a few of the figures in the Handbook would have benefitted from use of color. If the reader does not already know the concept or property depicted by the chart or illustration, it is difficult to discern the attribute being illustrated from the text and figure. Admittedly, the volume by Buchanan et al. (2000) was designed as a text and therefore has the purpose of relating new concepts to the reader. In fairness to the Handbook, it has vastly more references listed than the book by Buchanan et al. (2000). This lack of illustrations may limit the usefulness of the Handbook as a basic textbook. The extensive citations in the Handbook may serve to offset this limitation.

The title of the book lists "plant" before "crop." This listing is fitting in that a number of the topics covered in this book are more appropriate for a compendium of plant physiology review articles, but are not of the practical, yield-oriented nature generally associated with crop physiology. An example of a chapter that may have limited appeal to crop scientists is Developmental Genetics of Lower Plants. In contrast, the chapter entitled Photosynthetic Efficiency and Crop Yield should interest both plant and crop physiologist.

The Second Edition, like the initial volume, is constructed as a series of review articles, chapters, written by authors knowledgeable in the various areas of plant and crop physiology covered by the book. As one must expect with a work produced by a large number of authors, these chapters vary in length, coverage, depth and breath, and readability, but in general each chapter provides a detailed review of current knowledge of the topic covered.

The book is divided into 12 parts with one to nine chapters within each of the parts. Parts are entitled: Plants/Crops Growth Responses to Environmental Factors and Climatic
Changes; Physiology of Plant/Crop Growth and Development Stages; Cellular and Molecular Aspects of Plant/Crop Physiology; Plant/Crop Physiology and Physiological Aspects of Plant/ Crop Production Processes; Plant Growth Regulators: The Natural Hormones (Growth Promoters and Inhibitors) and Plant Genes; Physiological Responses of Plants/Crops Under Stressful (Salt, Drought, and Other Environmental Stresses) Conditions; Physiological Responses of Plants/Crops to Heavy Metal Concentration and Agrichemicals; Physiological Relationships Between Lower and Higher Plants; Physiology of Lower-Plant Genetics and Development; Physiology of Higher-Plant/Crop Genetics and Development; Using Computer Modeling in Plant Physiology; and Plant/Crop Physiology Under Controlled Conditions, in Space, and on Other Planets. Compared with the original volume, these Parts, and the chapters within, have been changed extensively. Few, if any, topics in the original were removed; many topics have been added, almost all chapters have been expanded or updated to included discoveries and literature published since the original chapters were completed.

In summary, the Handbook of Plant and Crop Physiology, Second Edition is a massive compendium of detailed current reviews on 48 topics in plant and crop physiology ranging in topics from molecular and cellular functions and processes to canopy responses to environmental conditions and change. The number of literature citations in all chapters is very impressive and should serve as a rich source of background or additional information for the reader. Although this volume may serve as a supplementary text for students in crop or plant physiology, the chapters are not written with sufficient background information to serve as a primary text. The writing style will make this volume most useful for advanced plant or crop physiology students or researchers attempting to improve and expand their knowledge in new areas of interest. Linking the many citations and details offered in this volume with a more instructive text on underlying principles and processes of physiology should make a valuable combination for those wanting to advance their knowledge though self study.

Buchanan, B.B., W. Gruissen, and R.L. Jones. 2000. Biochemistry and Molecular Biology of Plants. American Society of Plant Physiologists, Rockville, MD.

W.W. Wilhelm $U S D A-A R S$ 117 Keim Hall-UNL

Lincoln, NE 68583-0934 (wwilhelm1@unl.edu) 